\title{
RISK FACTORS OF BREAST CANCER IN MEDAN, NORTH SUMATERA
}

\author{
Rini Astuti Damanik, Namora Lumongga Lubis, Asfriyati \\ Masters Program in Public Health, Universitas Sumatera Utara
}

\begin{abstract}
Background: Breast cancer remains a major public health problem. The incidence is rising in most countries and is projected to rise further over the next 20 years despite current efforts to prevent the disease. Studies in to risk factors of breast cancer in Indonesian population are lacking. This study aimed to determine risk factors of breast cancer in Medan, North Sumatera.

Subjects and method: This was a case-control study conducted at Murni Teguh Memorial Hospital, Medan, North Sumatera. A sample of 100 women of reproductive age was selected for this study, consisting of 50 women with breast cancer and 50 women without breast cancer. The dependent variable was breast cancer. The independent variables were menarche age, use of hormonal contraceptive, obesity, stress level, and family history of breast cancer. The data of breast cancer cases were taken from the medical record. The other data were collected by questionnaire. The data were analyzed by a multiple logistic regression.

Results: The risk of breast cancer increased with late menarche age $(\mathrm{OR}=2.91 ; \mathrm{p}=$ $0.042)$, use of hormonal contraceptive $(\mathrm{OR}=3.09 ; \mathrm{p}=0.024)$, obesity $(\mathrm{OR}=3.00$; $\mathrm{p}=0.027)$, high stress level $(\mathrm{OR}=2.37 ; \mathrm{p}=0.003)$, and family history of breast cancer $(\mathrm{OR}=2.43 ; \mathrm{p}=0.001)$.

Conclusion: The risk of breast cancer increased with late menarche age, use of hormonal contraceptive, obesity, high stress level, and family history of breast cancer.
\end{abstract}

Keywords: breast cancer incidence, risk factors

\section{Correspondence:}

Rini Astuti Damanik. Masters Program in Public Health, Universitas Sumatera Utara, Medan, North Sumatera. Email: rinidamanik2010@gmail.com.

Mobile: 081375005499. 